\title{
Limbo in development projects
}

\author{
Lars Bo Andersen \\ This is the Accepted Manuscript of an article published in Development in \\ practice, available online at \\ https://doi.org/10.1080/09614524.2019.1607824.
}

\begin{abstract}
This article uses Actor-Network Theory to investigate how a One Laptop per Child project went through periods of impasse and crisis, what happened during these periods, and how the project managed to continue. The analysis shows that the standstills occurred when the understandings or "translations" behind the project started to unravel and, similarly, that the project was revitalised by participants experimenting with new translations. The article develops a sensitising concept called limbo intended to guide others confronted with similar situations. The concept has three traits: standstills are circumstantial, they entail ambiguity, and they are sources of project transformation.
\end{abstract}

\section{Introduction}

Development projects tend to proceed in ways unforeseen and unintended (Dodson, Sterling, and Bennett 2012; Ika 2012). There are many, well described and interrelated reasons for this: insufficient project management (Boakye and Liu 2016), lack of cultural understanding (Ika 2012) and universal top-down approaches to complex and situated problems (Easterly 2007). But there is also growing appreciation among researchers and practitioners alike, that no matter how well a project is designed and managed, the complex interplay between actors in and around that project will inevitably produce unforeseen challenges which can only be negotiated as they occur (Maclay 2015; Heeks 2002).

This article uses Actor-Network Theory (ANT) to investigate one such challenge and propose a way to understand and engage similar situations in other projects; namely the challenge of otherwise successful projects coming to a standstill. The article is 
occasioned by a study of the One Laptop per Child (OLPC) initiative and a project working to implement OLPC laptops at a small primary school in Nigeria called Makaranta. The project attracted a lot of support but also went through periods of crisis and impasse where it stood still while participants struggled to figure out what to do. Three research questions are investigated in relation to these periods: (1) How did the standstills develop? (2) What happened while the project stood still? And (3) how was the project revitalised following the standstills? The questions are investigated with ANT, which is used to follow how different actors "translated" both the OLPC initiative in general and the project at Makaranta in particular, and how these translations substantiated and shaped the project in different ways during its lifespan (Callon 1986; Scott-Smith 2014).

The article finds that the standstills developed through an interplay of many different events both in and outside the OLPC project. For example, a new IP address for a name server and the election of a new bishop in the local community both contributed to standstills. These events are rather mundane and, perhaps, unsurprising, but nonetheless ended up affecting the project in ways which were difficult to avoid. Another finding is that the project lost coherence and became ambiguous during the standstills which, in turn, entailed that these periods were negotiated in seclusion from the normal order of projects. Finally, it is illustrated how the standstills were overcome through trans- formations of the project, with new goals created and new participants enrolled.

The article proposes a sensitising concept called limbo as a way to help both practitioners and researchers understand and engage similar situations in other projects. There are at least two origins of the word limbo (Online Etymology Dictionary 2019): in Catholic mythology, limbo (from Latin limbus: edge, border) is a place on the margin of hell for those neither condemned nor redeemed; and in Caribbean folklore, limbo (from English limber: pliant, flexible) is a dance which reenacts the forced transformation of African people into colonial slaves during the Middle Passage. In both cases, limbo conceptualises a transient and marginal state of existence which - together with existing work on liminality (from Latin limen: margin, threshold, cross-piece) from anthropologists like Victor Turner - will be used to explicate three sensitising traits of projects in limbo: (1) that standstills are circumstantial and, as such, hard to manage or predict; (2) that projects standing still are ambiguous or even scandalous to participants and the outside world; and (3) that standstills may configure movements towards project transformations. 


\section{Learning from sensitising concepts}

Development projects involve a large array of heterogeneous stakeholders, they target some of the world's most difficult and entrenched problems, and are conducted under changing and somewhat unpredictable circumstances (Ika 2012). The combined consequence being that many projects unfold in ways unforeseen or unintended and struggle to create the intended outcomes (Ika 2012; Easterly 2007). This is also the case for the recent wave of development initiatives like OLPC focusing on creating social change through information technology (Dodson, Sterling, and Bennett 2012). Thus, it appears to be a basic premise that development projects cannot fully contain the complexity and unpredictability of their environment and, as such, require dynamic responses and continuous "repair work" if they are to succeed (Mikalsen, Farshchian, and Dahl 2018; Rhodes 2009).

On this background, one important and often overlooked way to create better projects is to develop ways for practitioners to "act out" unforeseen problems through situated learning, experimentation and interaction (Ika 2012; Scott-Smith 2014). Maclay (2015), for instance, has argued that blueprint approaches to project management leave too little room for practitioners to be dynamic, adaptive and responsive. Heeks (2002) has emphasised the importance of improvisation and experimentation when adapting projects to local needs and circumstances.

Following a similar approach, this article proposes that "sensitising concepts" may be a viable way for practitioners to learn from the experience of others while acting out problems of their own. From their position in grounded theory, sensitising concepts are constructed around the assumption that all empirical situations are different and require different forms of action (Blumer 1954). As such, they do not prescribe certain forms of action, or steps of analysis, but attempt to open up grounds for independent action by sensitising the analyst towards what might be at stake. But whereas most sensitising concepts have been designed primarily for research purposes, the concept of limbo is intended to provide intuitive clues and suggestions to a broader audience of both researchers and practitioners confronted with projects standing still.

\section{Development projects as actor-networks}

Actor-Network Theory (ANT) is an appropriate theory for the purpose of investigating how development projects grow, succeed, fail or become caught in crisis and impasse 
(see, for example, Scott- Smith 2014). In general, ANT conceptualises projects as networks of relations between actors of all types who compose and configure these projects (Callon 1986; Latour 1996). This is the crux of the notion of "actor-network"; that what enable projects to become "actors" capable of creating change for those involved are networks of other "actors" transgressing the formal boundaries of those projects (Scott-Smith 2014). The analytical implication of the actor-network ontology being that anything or anyone who plays a role in the empirical reality of a project is included in the analysis and treated in ways "symmetrical" to each other (Latour and Woolgar 1986, 274; Callon 1986). A priori or universal claims to truth, rationality or appropriateness are thus suspended in order to scrutinise how things play out in concrete and situated interaction.

With ANT, the analytical task is to trace through the network of actors in order to investigate how these shape and sustain a given project. This is generally done through the notion of "translation" which designates the process through which actors translate their differences into a collectively composed project which, in turn, is transformed and configured through these translations (Callon 1986; Latour 1996). Similarly, the below analysis of the OLPC project consists in tracing the translations which helped establish the OLPC initiative around 2005, those which led to the creation of the Makaranta project in 2009 and those which caused standstills to develop along the way. Table 1 provides an overview of the empirical material behind the analysis (Andersen 2013).

\begin{tabular}{|l|l|l|}
\hline Period & Event & Empirical material \\
\hline $2005-7$ & OLPC is launched. & $\begin{array}{l}\text { A review of research literature on OLPC, } \\
\text { interview transcripts from the now closed } \\
\text { OLPCTalks.com website and the published } \\
\text { memoirs of OLPC co-founder Walter Bender } \\
\text { and director Charles Kane (Bender et al. } \\
\text { 2012). }\end{array}$ \\
\hline $2007-8$ & $\begin{array}{l}\text { The OLPC initiative is standing } \\
\text { still. }\end{array}$ & $\begin{array}{l}\text { Semi-structured interviews with people } \\
\text { associated with OLPC, media coverage and } \\
\text { the memoirs of Walter Bender and Charles } \\
\text { Kane. }\end{array}$ \\
\hline 2009 & $\begin{array}{l}\text { The Makaranta project is } \\
\text { launched. }\end{array}$ & $\begin{array}{l}\text { Ethnographic fieldwork at Makaranta and in } \\
\text { Denmark. }\end{array}$ \\
\hline $2010-11$ & $\begin{array}{l}\text { The Makaranta comes to a } \\
\text { standstill. }\end{array}$ & $\begin{array}{l}\text { Ethnographic fieldwork at Makaranta and in } \\
\text { Denmark. }\end{array}$ \\
\hline
\end{tabular}




\begin{tabular}{|l|l|l|}
\hline $2012-13$ & $\begin{array}{l}\text { A new life for the Makaranta } \\
\text { project. }\end{array}$ & $\begin{array}{l}\text { Telephone interviews with staff from } \\
\text { Makaranta and interviews with participants } \\
\text { from the Danish NGO. }\end{array}$ \\
\hline
\end{tabular}

Table 1: Overview of empirical material collected for the analysis.

\section{5: gathering a network capable of providing One Laptop per Child}

In the early 2000s, researchers from the MIT Media Lab, such as Nicholas Negroponte, Walter Bender and Seymour Papert, managed to gather a network of very different actors around their One Laptop per Child (OLPC) initiative. The ambition was quite literately to provide every impoverished child in the world with a purpose-built laptop for learning. The actors translated into the project through a specific problematisation - a proposed way of arranging the world so that one's own project can be translated as the solution to someone else's problem (Callon 1986; Luyt 2008). Negroponte outlined the OLPC problematisation:

How do you eliminate poverty? The answer is simple: education. [...] OLPC leverages the children themselves, bringing the learning medium into their lives $24 \times 7$, at a total cost of a dollar per week ... (Negroponte 2010)

Education will solve the problem of poverty, OLPC argued, and given that MIT research shows that children will be able to learn with computers without any assistance from adults, OLPC can eliminate poverty through low-cost laptops at a total cost of one dollar per child per week (Papert 1993; Negro- ponte 2010).

The problematisation allowed a range of actors to translate into the project network. Negotiations were carried out with heads of state from major developing countries, which not only associated OLPC with educational development, but also considered the initiative a prominent way to bridge the structural inequalities associated with the digital divide (Luyt 2008). This translation was given strength when Negroponte presented an early laptop prototype at the World Summit on the Internet Society (WSIS) alongside then-UN Secretary General Kofi Annan, who praised the laptop and called it a powerful catalyst of development (UN News Releases 2005). The WSIS process was explicitly intended to identify ways to bridge the digital divide and Negroponte went there to put an (afford-able) solution on the table (WSIS 2005). Soon after, heads of state from Brazil, Libya, Argentina, Nigeria and Thailand pledged to buy one million laptops each (Bender et al. 2012, 78). 
OLPC also needed what they called the "capitalistic machinery" to help design and manufacture the low-cost laptops (MacMullin 2007). At the World Economic Forum and during meetings with companies like Quanta, AMD, Red Hat and Google, Negroponte proposed that OLPC should be considered a business opportunity rather than a charity - both by virtue of the numbers of laptops to be produced and as a strategic way to gain foothold in developing markets (Bender et al. 2012, 82; OLPC Talks 2006). The proposition worked and companies translated the OLPC initiative into future profits which, in turn, provided the initiative with both production facilities and help with design and development of laptops (Bender et al. 2012, 82; OLPC Talks 2006). In ANT terminology, the OLPC problematisation had helped mobilise a network of actors capable of translating very different agendas into a project of providing one laptop per child (Callon 1986).

\section{7: a standstill of unmaterialised translations}

Social bonds and oral agreements are only durable if they can be "materialised" into socio-technical translations such as signed contracts backed by legal institutions (Strum and Latour 1987). Similarly, the oral agreements with heads of states did not amount to confirmed sales of actual laptops. There were many and somewhat circumstantial reasons for this. In Thailand, Thaksin Shinawatra was ousted in a military coup (Plate 2011, 59). In Libya, Gaddafi simply walked away (Vota 2009). In Brazil, Lula decided to instigate a general bidding round for 150,000 inexpensive laptops, which OLPC lost (Van de Sande 2007). In Nigeria, Olusegun Obasanjo hosted a pilot project but then paused the project until he was replaced in office by Umaru Yar'Adua, who discontinued further collaboration with OLPC (Bender et al. 2012, 67; Vota 2008).

In consequence, the OLPC initiative was caught at a standstill and under great pressure from their corporate backers to start selling laptops (Bender et al. 2012, 78). OLPC was in a predicament: They risked impending failure if they stayed true to their hitherto strategy. And if they pursued other and more modest business models instead, they would compromise their successful problematisation of OLPC as nothing less than the solution to poverty. Meanwhile, OLPC managed to keep the scandalous reality of unsold laptops out of the extensive and mostly favourable media coverage and also dissuaded their board of directors from formally discussing the situation (Bender et al. 2012, 78). 


\section{8: from development machines to consumer devices}

After about a year, the OLPC initiative gained renewed momentum when their laptops were tempor- arily translated from development machines into consumer devices. In the Christmas sales of 2007 and 2008, OLPC partnered with Amazon in the so-called "Give One, Get One" (G1G1) programme where Western consumers could buy an OLPC laptop for themselves and, in turn, sponsor another laptop to be used for development purposes. Launched at the height of OLPC's media hype, the programme successfully circumvented the lack of governmental partners by selling 90,000 laptops to private consumers who, in turn, sponsored another 90,000 for development projects. G1G1 thus provided the necessary sales to keep corporate backers aligned and also provided countries such as Peru and Uruguay with enough confidence to place the first substantive orders of 260,000 and 100,000 laptops, respectively (Bender et al. 2012, 82).

While the G1G1 programme was a necessary detour, OLPC subsequently pursued this translation further and in ways more controversial to people both in and outside the initiative. Most importantly, when it was subsequently decided to replace the open source Sugar operating system, which had been tailored for children's learning, with the more consumer-oriented Microsoft Windows, many felt that OLPC betrayed both its educational mission and its principle commitment to open source software (OLPC Wiki 2007). Consequently, key employees such Walter Bender (a OLPC co-founder) resigned and many software contributors felt estranged (DeKoenigsberg 2008; Lohr 2008). While OLPC eventually returned to Sugar, they have since continued to pursue their "consumer-device" translation in other ways, most recently by licensing the OLPC brand to commercial Android products sold through Toys"R"Us and Walmart (Estes 2014; Bender et al. 2012, 82).

\section{9-2010: laptops aimed at IT literacy and open-open learning}

Before the standstill in 2007, OLPC enforced a policy of only collaborating with nation states and only around projects with more than one million laptops involved. But the G1G1 programme created a surplus of unsold laptops which OLPC then offered to NGOs for small-scale projects. One of these was a Danish NGO with a long tradition of educational projects in Nigeria. They translated the OLPC initiative into a means of replacing rote learning and the use of physical punishments with more appreciative and open-ended forms of learning. 
The NGO partnered with a school called Makaranta which, at the time, was looking for ways to fund a computer lab for their students. It is mandated by the national curricula in Nigeria that primary students become IT-literate, which in this context means to be knowledgeable about the most common aspects of operating computers and using software such as Microsoft Windows and Office. The school was using paper models of software and computers to teach IT literacy and the OLPC project offered a good way to replace these with actual computers.

In mid-2009, the OLPC project at Makaranta commenced with a series of workshops where the teachers were trained in using laptops and Scandinavian variants of the constructionist pedagogy promoted by OLPC. The teachers were also told that this new pedagogy was incompatible with the use of physical punishments. The following year the project was a success. Enticed by promises of IT literacy more and more parents transferred their children to the school, which quickly became full. In conversations with students, teachers and parents, they all relayed great enthusiasm for the project, as exemplified by one excited teacher:

I was taught about computers in college and I did not understand anything about it, it was just a picture on a piece of paper. So, students normally pay a lot of money to learn how to operate actual computers. So, in three years, our school is going to be the best school in the state. (Teacher, interview, 2009)

Following the pedagogical workshops, teachers started introducing learner-centred activities and the "bulalas" (rattan canes) were stowed away with the empty cardboard boxes in which the laptops came. A typical example of a lesson with the laptops was to have students choose a subject to research on their laptop, either using Google or Wikipedia, and then present their findings to the class. These new types of learning activities were promoted by the school as their "open-open" approach to education: open towards different didactical methods and open towards different learning outcomes for different students.

\section{0-11: a project starting and stopping with technical repairs}

Actor-networks, such as that at Makaranta, have to be maintained in existence (Latour 2005). Both the school and the NGO were well aware of this and had tried to make the project sustainable in a number of ways - both in relation to the technical infrastructure described here, and the management of teachers described below. 
Without a stable supply of electricity in the area, the project utilised solar panels and batteries to power the laptops. Internet was ensured via a satellite connection and routed to laptops through a linux server and access points in all classrooms. The setup had been installed and was maintained by local engineers aided by an American consultant.

After about a year, however, this constellation was challenged by a series of unfortunate events. To begin with, the internet service provider changed the IP address of their DNS server. This was a minor technical detail but it nonetheless took the local technician several months to update the linux server in a way where it did not default back to the old IP a few days later. At the same time, the batteries storing the electricity generated by the solar panels died and money had to be raised for new ones. Then the roof carrying the panels collapsed under their weight and the installation had to be moved to a purpose-built metal tower. When everything was finally brought back to working order, it turned out that the wireless access points had died from the Harmattan dust and money had to be raised again.

All these problems were eventually overcome. But they entailed three periods with no electricity and internet, which together lasted for most of a year, and which eroded the translations of laptops as means of IT literacy and open-open education. The lack of electricity hampered the project in obvious ways. But the lack of internet was also important as browsing for pictures or researching subjects on Google were among the favourite learning activities for many teachers. As argued by the fine arts teacher, the laptops were didactically "empty" without internet:

Take for instance I who are teaching art. If I want to google pictures of Egyptian art, of the Pharaoh, and how he decorated his palace. You know these "empty" computers, I can't use them for achieving my objective. So, in this kind of lesson the computers cannot help me, I have to drop them! (Teacher, interview, 2011)

During this period, teachers gradually got out of the habit of teaching with laptops, which was still a new and demanding form of teaching, and fell back to their old methods of rote learning at the black- board. Since the school feared that laptops would be stolen or broken if used outside of class, stu- dents no longer had any opportunity to use laptops - much to their frustration, as illustrated in an interview with a Primary 5 student, who recently transferred to Makaranta because of the OLPC project: 
My mother told me that she wants me to have opportunities with the computers [... ] But uncle! When it is time for computer practice, last week we had computer practice, the teacher refused to give us the computers. And then again, this Friday, he refused to give us them. (Primary five student, interview, 2011)

\section{1: a complete standstill}

The following year, the technical problems were surpassed by other events which further undermined the network and created a complete standstill. During 2010 and 2011 many teachers left the school and the replacement teachers hired were not trained in the open-open pedagogy and neither did they feel comfortable using laptops in their classes as they had only limited experience using computers. This situation was allowed to happen because a local bishop, who had served as an informal project manager, was replaced and his successor had other priorities. Without a highranking community member actively supporting and monitoring the project, no efforts were made to train the new teachers and it became a tendency for both new and old teachers to sit idle in the staff room for most of the day. The school principal, while formally in charge, did not feel he had a mandate to do much about the project or enforce sanctions on the idle teachers (Principal, interview, 2011).

At first, the standstill went unnoticed at the Danish NGO. As argued by one teacher, the school practiced a "things are fine" strategy towards the outside world (Teacher, interview, 2011). However, when the NGO decided to send volunteer workers to help with the project, they became aware of the situation. The volunteers wrote a public newsletter in which they praised the project for its opportunities. But they also wrote a confident report to the NGO stating that teachers were sitting in the staffroom while laptops were sitting unused in the computer room (interview with volunteers, 2012). The report stirred some "mighty discussions" at the NGO, which silently removed the project from their formal portfolio while trying to figure out what to do (participant observation, 2012).

Meanwhile, parents were becoming impatient and started to withdraw their children from Makaranta. During spring 2011, for instance, Primary 5 went from 25 students to only seven, and in late 2011 it became clear that neither the school nor the OLPC project could continue as before. A meeting was arranged between project participants from both Denmark and Nigeria to discuss ways of revitalising the project. At the meeting, the Makaranta management was mostly concerned with maintaining 
the technical installations while the NGO was more concerned about the poor quality of teaching. Frustrated by the situation, one of the Danes exclaimed: "We might as well have bought laptops from Intel rather than these laptops meant for learning" to which the school principal argued that without money and support for the internet and electricity, the laptops were no longer relevant for their purpose of providing IT literacy (observation, 2011). Two of the most important translations upholding the project could no longer be accommodated by the OLPC laptops which, in consequence, remained unused.

\section{2: a project dedicated to IT literacy}

The OLPC project was not only at a standstill, it was also in an ambiguous state between what it had been before and what it could still become. As such, in 2012 participants tried to address this ambiguous situation to again make a proper project around the laptops. The school principal, for instance, was eager to build a commercial internet café using the laptops. Such a café had unofficially existed from the outset with adults from the community using the internet and laptops after school hours. Wanting to formalise and expand this idea, he drafted a business plan with the support of the school board. The Danish NGO also supported his idea, although only on the condition that it would also serve educational purposes for the school's children.

The café, however, never went beyond what already existed unofficially. In the end, the standstill was cleared by rearranging the project into a dedicated IT literacy project. Around the same time as laptops arrived at Makaranta, a local philanthropist donated a large amount of money for a new school building. The new building included a new science lab connected to both the solar panels from the OLPC project and a large diesel generator of its own. In early 2013 the principal decided to move the laptops to the science lab and use them for IT literacy sessions for all classes above Primary 4. But since the NGO could no longer translate the project into pedagogical development, they eventually withdrew to focus on other projects. The OLPC project at Makaranta thus ended with a few stable years in the science lab as a supplement to paper models in the school's efforts to make students IT-literate.

\section{A sensitising concept of project limbo}

In order to summarise and further analyse the standstills in the OLPC project in a way which is useful for others, a sensitising concept is proposed. The idea is simply to designate the situation of projects standing still through the metaphor of "limbo" and 
to explicate three "sensitivities" from this metaphor: (1) that limbo is a circumstantial situation; (2) that projects in limbo are ambiguous and fall between the normal states of projects; and (3) that limbo is not as much a static state as a movement towards change and transformation. Concretely, the sensitivities are developed by relating findings from the OLPC project to selected traits from the dual origin of the word limbo in Catholic mythology and Caribbean folklore as well as existing literature on liminal transitions.

\section{First sensitivity: limbo develops out of circumstance}

In the OLPC project, limbo was caused by faltering translations in the project network. As such, it developed from many different sources and in many different yet interacting ways. Likewise, the inherent innocence and circumstantial condemnation of those in limbo is a defining trait of both the Catholic and Caribbean forms of limbo. In Alighieri's (1306) Divine Comedy, for instance, limbo (from Latin limbus: edge, border) is a place at the outskirts of hell for those neither condemned nor redeemed, those who died with their original sin but committed no sin themselves. As such, limbo is set apart from the other eight circles of hell by non-causality between sin and condemnation. In the other circles, the torment reflects the sin. Those who were lustful in life, for instance, are condemned to the second circle where they suffer an endless whirlwind blowing them around, punishing their aimless, restless desire (Alighieri $1306,268)$. But in limbo there are no sins to be reflected in the punishment, it is more like a waiting room, and Dante finds in limbo both Greek philosophers and Muslim dignitaries filling him with great grief that people of much worthiness should be suspended like this (Alighieri 1306, 16).

The simple but far reaching implication in relation to projects is that limbo may develop in even the most well-designed and well-managed projects; that it is a state caused by non-linear and circumstantial developments in the networks of projects and, as such, outside the reach and control of any one position in those networks.

\section{Second sensitivity: projects in limbo fall between categories}

During its standstills, the OLPC project was caught in a halfway existence between what it had been, and was no more, and what it could still become in the future. An initiative which could no longer provide millions of laptops, but perhaps 100,000 . Or a project which could no longer facilitate a pedagogical transformation at Makaranta but perhaps still provide IT literacy. This halfway existence is characteristic of limbo 
as a state between states, a transient position located at the margin of order, for those neither condemned nor redeemed, as described by Dante and enacted in the Caribbean limbo described below (Alighieri 1306).

Importantly, such halfway positions are not only important in folklore and mythology but in all transitions between established categories in social organisations. This is well described in anthropolgy in relation to the so-called "rites de passage" - rituals which facilitate either major life changes such as birth, marriage and death, or unforeseen life crises such as a failed harvest or the outbreak of war (Gennep 2006; Turner 1967). Central to these rituals is the "liminal period" (from Latin limen: margin, threshold, cross-piece) where subjects are pushed into a secluded or marginal existence, much like that of Dante's limbo, where they are exempt from the normal order of society (Turner 1967). During a puberty rite, for instance, a boy is sent into the bush where rituals allow him to leave childhood and enter into manhood. But during the transitional period the boy-not-yet-man is neither-or and, as such, a scandalous paradox in relation to the recognised categories of his society which, in consequence, secludes him until the transformation is complete (Turner 1967, 95).

Similarly, when projects are standing still, they inhabit an intermediate position between the formally recognised categories of existence which, for projects, commonly includes the expectation that they are progressing towards their predefined goals. In cases such as OLPC the non-progression may cause projects to be negotiated either in seclusion from other projects, such as when the NGO removed the project from their formal portfolio, or behind the pretence that the project belongs to a more acceptable category, such as when the Makaranta school practiced a "things are fine" strategy.

\section{Third sensitivity: limbo is a movement of change and transformation}

Turner $(1967,94)$ designates liminality as a dynamic state of transformation behind a calm surface, like a pupa or water being heated to the point of boiling. And because liminal states are exempt from normal order, they are often associated with creativity and innovation (Fabre 1999; Söderlund and Borg 2018). Similarly, while limbo is the situation for projects in crisis, it is also a movement towards change and transformation.

The duality between being caught in a crisis and the possibility of change is well described by the Caribbean dance of limbo (from English limber: pliant, flexible). In 
this limbo, dancers passing under the stick are enacting a liminal passage of deep historic and cultural significance. Namely the forced transformation of African man into colonial slave during the Middle Passage of the European slave trade (Fabre 1999; Brathwaite 2002). During the passage, the former Igbo, Yoruba or Ashanti are forced into a state of decomposition and catabolism, to use Turner's (1967) terminology. But those who survive the passage arise in celebratory defiance from under the stick. Meanwhile, the dancers are neither redeemed nor have they remained Africans. Instead, they find themselves transformed and translated into new forms of existence in the plantations.

Caribbean limbo evokes a resilient imagination of new and better transformations in the face of crisis and oppression (Fabre 1999). But Caribbean limbo also serves to remind us that limbos may repeat themselves once cleared and that liminal passages do not operate as a dialectic. They simply configure movements from one situation to another, where the latter is not necessarily better than the former. At Makaranta, for instance, the OLPC project was saved by the move to the science lab. But if evaluated by its ability to facilitate educational development, the science lab was not a good escape for the project nor the children at the school, who are now back to rote learning and strict physical discipline.

\section{Conclusion}

The success and sustainability of development projects are central concerns in both theory and practice. While much can be done to improve the management of projects, or the appropriateness of their underpinning ideology, there are also some challenges which cannot be fully avoided ex ante but must be acted out as they arise through the specific circumstances of each project (Maclay 2015). This article investigated one such challenge which happened several times in a OLPC project; the challenge of projects coming to unexpected standstills. ANT and the notion of translation were used to analyse how the standstills developed, what happened during the standstills and how they were overcome.

The analysis showed that the standstills developed when unforeseen events undermined the translations upholding the project-network. After a successful mobilisation of a network consisting of private companies, the UN system, and major developing countries the OLPC initiative came to its first standstill when oral commitments from heads of state did not materialise into legally binding orders. This, in turn, undermined the translation of OLPC as a major business opportunity and the 
whole initiative came close to disintegration. Similarly, at Makaranta, the project started and stopped with the maintenance of solar panels and internet connection, and the work of maintaining the teacher's commitment to the open-open approach. When a local bishop was replaced and a new group of teachers hired, the laptops disappeared from the classrooms altogether.

In all cases, to the outside world, the standstills were treated as if they were not occurring at all. The volunteers visiting Makaranta only talked about opportunities in their public communication, the Danish NGO silently removed the project from their formal portfolio, and the Makaranta school pre- tended that everything was fine. But below the calm surface, the standstills were quite busy periods where actors tried to revitalise the project through novel translations. Different propositions were negotiated, such as the afternoon Internet café, and those which could be translated by others ended up saving the project - like the G1G1 programme or the IT literacy sessions in the science lab.

These findings were synthesised in a sensitising concept called limbo intended to enable others to learn from the experience of the OLCP project. Sensitising concepts are appropriate for this end because they provide initial guidance towards a situation without prescribing actions or even assuming that it is the same situation as that of the OLPC project. They lend themselves to be translated by others, so to speak.

\section{Acknowledgements}

The author would like to thank project participants for openly sharing both ups and downs and for generously letting me follow them around.

\section{References}

Alighieri, Da. 1306. The Divine Comedy. FeedBooks. Accessed 2 Novermber 2018. www.feedbooks.com/book/206/the- divine-comedy

Andersen, L. B. 2013. A Travelogue of 100 Laptops - Investigating Development, Actor-Network Theory \& One Laptop per Child. Aarhus: Aarhus University.

Bender, W., C. Kane, J. Cornish, and N. Donahue. 2012. Learning to Change the World: The Social Impact of One Laptop per Child. New York: Palgrave Macmillan. 
Blumer, H. 1954. "What Is Wrong with Social Theory?” American Sociological Review 19 (1): 3-10.

Boakye, L., and L. Liu. 2016. "With the Projectisation of the World, The Time Is Right to Unravel Why International Development Project (IDP) Failure Is Prevalent." Universal Journal of Management 4 (3): 79-89.

Brathwaite, E. K. 2002. "Limbo." In Working with the English Anthology for AQA A, 2004-2006, edited by I. Pilgrim, L. McNab, and P. Thomas, 12-17. Oxford:

Heinemann Educational.

Callon, M. 1986. "Some Elements of a Sociology of Translation - Domestication of the Scallops and the Fishermen of St. Brieux Bay." In Power, Action, and Belief - A New Sociology of Knowledge, edited by J. Law, 196-223. London: Routledge \& Kegan Paul. DeKoenigsberg, G. 2008. "OLPC Developers Are Not Open Source Fundamentalists.” OLPC News. Accessed 2 November 2018. http://www.olpcnews.com/people/negroponte/open_source_fundamentalists.html Dodson, L., R. S. Sterling, and J. K. Bennett. 2012. "Considering Failure: Eight Years of ITID Research." Information Technologies \& International Development 9 (2): 19-34. Easterly, William. 2007. The White Man’s Burden. London: Penguin Books.

Estes, A. C. 2014. “One Laptop Per Child Isn't Quite Dead Yet.” Gizmodo, March 12, 2014. Accessed 2 November 2018. https://gizmodo.com/one-laptop-per-child-isntquite-dead-yet-1541430670

Fabre, G. 1999. “The Slave Ship Dance.” In Black Imagination and the Middle Passage, edited by M. Diedrich, H. L. Gates, Jr., and C. Pedersen, 33-46. Oxford: Oxford University Press.

Gennep, A. van. 2006. The Rites of Passage. Abingdon: Routledge.

Heeks, R. 2002. "Information Systems and Developing Countries: Failure, Success, and Local Improvisations." The Information Society 18 (2): 101-112.

Ika, L. A. 2012. "Project Management for Development in Africa: Why Projects Are Failing and What Can Be Done About It." Project Management Journal 43 (4): 27-41.

Latour, B. 1996. Aramis, or, The Love of Technology. Cambridge, MA: Harvard University Press. 
Latour, B. 2005. Reassembling the Social: An Introduction to Actor-Network-Theory. Oxford: Oxford University Press.

Latour, B., and S. Woolgar. 1986. Laboratory Life: The Construction of Scientific Facts. Princeton, NJ: Princeton University Press.

Lohr, S. 2008. "Why Walter Bender Left One Laptop Per Child.” The New York Times. Accessed 2 November 2018. https://bits.blogs.nytimes.com/2008/05/27/whywalter-bender-left-one-laptop-per-child-edited-hold-for-wed-am/

Luyt, B. 2008. "The One Laptop Per Child Project and the Negotiation of Technological Meaning." First Monday 13 (6).

Maclay, C. 2015. "Management Not Models: Adaptability, Responsiveness, and a Few Lessons From Football." Development in Practice 25 (1): 42-57.

MacMullin, B. 2007. “Aurora Online with Mary Lou Jepsen.” Aurora, no. 2007. Accessed 2 November 2018. http://aurora.icaap.org/index.php/aurora/article/view/73/85

Mikalsen, M., B. A. Farshchian, and Y. Dahl. 2018. "Infrastructuring as Ambiguous Repair: A Case Study of a Surveillance Infrastructure Project." Computer Supported Cooperative Work (CSCW) 27 (2): 177-207.

Negroponte, N. 2010. "Laptops Work." Boston Review. Accessed 2 November 2018. http://bostonreview.net/BR35.6/negroponte.php

OLPC Talks. 2006. “OLPC Talks: Nicholas Negroponte at WCIT.” OLPC Talks. Accessed 2 November 2018.

https://web.archive.org/web/20130411034401/www.olpctalks.com/nicholas_negr oponte/negroponte_wcit.html

OLPC Wiki. 2007. “OLPC: Five Principles - OLPC.” Wiki.Laptop.Org. Accessed 2 November 2018. http://wiki.laptop.org/go/Core_principles/lang-en

Online Etymology Dictionary. 2019. "limbo." Online Etymology Dictionary. Accessed 2 November 2018. www.etymonline.com/word/limbo

Papert, S. 1993. The Children's Machine: Rethinking School in the Age of the Computer. New York: BasicBooks. 
Plate, T. 2011. Conversations with Thaksin: From Exile to Deliverance: Thailand's Populist Tycoon Tells His Story. Singapore: Marshall Cavendish Corp.

Rhodes, J. 2009. “Using Actor-Network Theory to Trace an ICT (Telecenter) Implementation Trajectory in an African Women's Micro-Enterprise Development Organization." Information Technologies \& International Development 5 (3): 1-20.

Scott-Smith, T. 2014. "How Projects Rise and Fall: The Lifecycle of a Dietary Modernisation Scheme." Development in Practice 24 (7): 785-796.

Söderlund, J., and E. Borg. 2018. "Liminality in Management and Organization Studies: Process, Position and Place." International Journal of Management Reviews 20 (4): 880-902.

Strum, S. S., and B. Latour. 1987. "Redefining the Social Link: From Baboons to Humans." Social Science Information 26 (4): 783-802.

Turner, V. W. 1967. The Forest of Symbols; Aspects of Ndembu Ritual. Ithaca, NY: Cornell University Press.

UN News Releases. 2005. “\$100 Computer for Children Unveiled by UN.” Accessed 2 November 2018. http://news.mongabay.com/2005/1117-laptop.html

Van de Sande, A. 2007. "David Cavallo Interview on OLPC Brazil's Apparent Loss.” OLPC News. Accessed 2 November 2018. www.olpcnews.com/countries/brazil/david_cavallo_olpc_brazil.html Vota, W. 2008. “OLPC Nigeria One Year Later: Hard Lessons Learned” OLPC News. Accessed 2 November 2018. http://www.olpcnews.com/countries/nigeria/olpc_nigeria_one_year_later.html Vota, W. 2009. “Was OLPC Libya Really a Gadhafi Marketing Ruse?!” OLPC News. Accessed 2 November 2018. www.olpcnews.com/countries/libya/was_olpc_libya_really_a_ruse.html WSIS. 2005. "WSIS: Tunis Agenda for the Information Society." Accessed 2 November 2018. www.itu.int/wsis/docs2/tunis/off/6rev1.html 